\title{
Comparing Emission Factors and Physicochemical Properties of Waste-Biomass Leaves of Selected Species of Trees
}

\author{
Grzegorz Maj ${ }^{1 *}$, Jolanta Piekut ${ }^{2}$ \\ 'Department of Power Engineering and Transportation, University of Life Sciences in Lublin, Lublin, Poland \\ ${ }^{2}$ Department of Agri-Food Engineering and Environmental Management, Białystok University of Technology, \\ Białystok, Poland
}

Received: 6 July 2017

Accepted: 9 October 2017

\begin{abstract}
This study describes the problems of managing biodegradable waste in the form of leaves in the thermochemical conversion process of waste biomass. The results of experimental studies of physicochemical properties of leaves of 4 selected tree species (i.e., oak, hazel, maple, and walnut) are shown. The study consisted of determining the energy parameters in the form of markings gross and net calorific value of the test material. In addition, the ash and moisture content of the material was tested. Moreover, an elementary analysis for the tested leaves by determining the content of carbon, hydrogen, and nitrogen was measured. The studies have shown great energy potential for the examined leaves, in particular oak leaves, where the gross calorific value amounted to $18.77 \mathrm{MJ} \cdot \mathrm{kg}^{-1}$, net calorific value of $17.70 \mathrm{MJ}^{-1} \mathrm{~kg}^{-1}$, and an ash content of $21.98 \%$. Oak leaves are also characterized by the highest carbon content of $47.66 \%$, hydrogen at $6.32 \%, 0.88 \%$ nitrogen, and sulfur $0.14 \%$. Determined emission rates indicate a reduction of $28-35 \% \mathrm{CO}, 24-53 \% \mathrm{NO}_{x}, 26-32 \% \mathrm{CO}_{2}, 53-60 \% \mathrm{SO}_{2}$, and $31-54 \%$ dust depending on the type of biomass used.
\end{abstract}

Keywords: biomass, leaves, energy, tree, emission factors

\section{Introduction}

Legal regulations in the European Union impose the obligation to implement a national solid waste disposal management system, including an efficient biowaste disposal management system [1-2]. The major objectives of the acquis communautaire include the aim of reducing the volume of municipal solid waste that is biodegradable. In order to solve that problem,

*e-mail: grzegorz.maj@up.lublin.pl it is necessary to implement new thermal treatment facilities for solid waste, including biowaste that is biodegradable [3] - particularly within the framework of the municipal solid waste disposal management systems in urban agglomerations and macroregions. To this end, technological arrangements should aim at reducing substantial volumes of biodegradable waste and concurrently generating electric energy and thermal power in terms of renewable energy sources [4-6].

Leaves, falling off trees, represent a kind of biomass that may be used for power generation purposes 
to a great extent [7-9]. When the latest work is being done, it is affecting the life of the city to spread the leaf of the leafy trees. Although leaves can absorb $\mathrm{CO}_{2}$, environmental pollution comes to the forefront when they are poured. Recent studies demonstrate how human health is affected by the quality with PM10 and $\mathrm{CO}_{2}$. Several studies on air pollution exposure have shown the problems concerning human health and fine particulate organic matter [10-14]. In autumn they cause huge problems in urban agglomerations since large quantities of leaves are carried away in the course of cleaning cities and suburbs in the autumn every year, to be mainly disposed of at landfill sites [15-16]. Incineration is not a very popular method of disposing leaves. The related literature treats it as an innovative approach and it has recently aroused interest to the extent of using it for urban power generation purposes [17].

Incineration of tree leaves may be an alternative approach to those that have already been applied, namely landfilling and composting. Furthermore, using leaves for power generation purposes will contribute to the production of alternative fuel in terms of the national energy-fuel balance [18]. This is significant due to insufficient fossil fuels. It needs to be emphasized that biomass is an ecological fuel since it maintains zero balance of $\mathrm{CO}_{2}$ in the atmosphere as a result of the incineration of leaves [19-21]. This is an additional advantage of using leaves for power generation purposes $[17,22]$. Thermal-and-chemical conversion of biomass is a process that does not cause any additional emission of $\mathrm{CO}_{2}$ into the atmosphere and which does not contribute to the greenhouse effect [23-25]. Reducing the emission of hazardous substances into the atmosphere is currently required and recommended by various global political and economic organizations [26-27]. The aim of reducing the emission of hazardous substances makes it necessary to seek innovative and ecological energy sources [28-30]. Incineration of leaves (biomass) in incinerators is normally preceded by the procedures of collecting, drying, and storing in adequate facilities, and finally grinding (in most cases).

The aim of our study was to perform physicochemical analysis of waste-biomass leaves and determine emission factors of individual gases and dust of selected species of trees in terms of their suitability for use for energy purposes and environment protection.

\section{Material and Methods}

Our research focused on leaves of four tree species: maple, hazel, oak, and walnut. The sampling procedure was compliant with the EN 14780 standard [31]. At the first stage of the research the leaf samples were disintegrated. They were first dried and purified. All the leaves were ground by means of the laboratory grinder IKA A 11 and underwent pre-selection.

The incineration gross and net calorific value were adjusted by means of the LECO AC 600 calorimeter in conformity with the EN 14918 standard [32]. The incineration gross calorific value was set as a result of the incineration of samples in conditions of ambient oxygen in a pressurized pot placed in water. The net calorific value was set by means of computer software and the input figures of water content and hydrogen content in the matter under consideration, according to the following net calorific value formula arising from the said standard (Eq. 1):

$$
Q_{i a}=Q_{s a}-24.43 \cdot\left(W_{a}+8.94 \cdot H^{a}\right)
$$

...where $\mathrm{Q}_{\mathrm{ia}}$ is net calorific value in analytical terms ( J'g-1), Qsa is gross calorific value in analytical terms $(\mathrm{J} \cdot \mathrm{g}-1), 24.43$ is water evaporation at $25^{\circ} \mathrm{C}$ (corresponding to $1 \%$ of water content in fuel), 8.94 is hydrogen content conversion rate, $\mathrm{H}^{\mathrm{a}}$ is hydrogen content in a sample in analytical terms (\%), and $\mathrm{W}_{\mathrm{a}}$ is water content in a fuel sample in analytical terms (\%).

Ash content was measured in conformity with the EN 14775 standard [33] and water content - in compliance with the EN 14774-1 standard [34]. For the purposes of the measurements, we used a LECO TGA701 thermogravimetric analyzer. Nineteen samples were automatically weighed by the device, and ash content and water content were measured on the basis of the weight loss of the matter after it had been heated up when being strictly controlled in the conditions of ambient oxygen. Water content of the sample was computed in analytical terms according to the following formula (Eq. 2):

$$
W_{a}=\left(\left(m_{1}-m_{2}\right) /\left(m_{1}-m_{3}\right)\right) \cdot 100
$$

...where $\mathrm{W}^{\mathrm{a}}$ is water content in analytical terms (\%), $\mathrm{m}_{1}$ is weight of the pot containing the sample before drying $(\mathrm{g}), \mathrm{m}_{2}$ is weight of the pot containing the sample after drying $(\mathrm{g})$, and $\mathrm{m}_{3}$ is weight of an empty pot $(\mathrm{g})$.

Ash content was measured in analytical terms in conformity with the EN 14775 standard [33] according to the formula (Eq. 3):

$$
A=\left(\left(m_{3}-m_{1}\right) /\left(m_{2}-m_{1}\right)\right) \cdot 100
$$

...where $\mathrm{A}$ is ash content in a sample in analytical terms $(\%), \mathrm{m}_{1}$ is weight of a calcined pot $(\mathrm{g}), \mathrm{m}_{2}$ is weight of the pot containing a sample $(\mathrm{g})$, and $\mathrm{m}_{3}$ is weight of a pot containing ash $(\mathrm{g})$.

Total carbon content (C), hydrogen content $(\mathrm{H})$, and nitrogen content $(\mathrm{N})$ were measured in conformity with EN ISO 16948:2015-07 [35] and sulfur EN ISO 16994:2016 standard [36]. The analysis was conducted by means of the CHNS 628 analyzer made by LECO. The process of measuring carbon content, hydrogen content, and nitrogen content was performed at $950^{\circ} \mathrm{C}$, and sulfur content (S) was analyzed in a separate module at $1,350^{\circ} \mathrm{C}$. 
Table 1. Results of technical and elemental analysis for the tested leaves.

\begin{tabular}{|c|c|c|c|c|c|c|c|c|}
\hline Material & $\begin{array}{l}\text { Oak tree } \\
\text { leaves }\end{array}$ & $\begin{array}{l}\text { Maple tree } \\
\text { leaves }\end{array}$ & $\begin{array}{l}\text { Hazel tree } \\
\text { leaves }\end{array}$ & $\begin{array}{l}\text { Walnut tree } \\
\text { leaves }\end{array}$ & $\mathrm{F}$ & $\begin{array}{c}\mathrm{p}- \\
\text { value }\end{array}$ & $\mathrm{F}_{\mathrm{w}}$ & $\begin{array}{c}\mathrm{p}_{\mathrm{w}}{ }^{-} \\
\text {value }\end{array}$ \\
\hline $\begin{array}{l}\text { Gross calorific value }\left(\mathrm{MJ} \cdot \mathrm{kg}^{-1}\right) \\
\qquad \pm \mathrm{S}_{\mathrm{x}}\end{array}$ & $\begin{array}{l}18.58 \mathrm{a} \\
\pm 0.03\end{array}$ & $\begin{array}{l}18.00 \mathrm{~b} \\
\pm 0.56\end{array}$ & $\begin{array}{l}17.41 \mathrm{c} \\
\pm 0.24\end{array}$ & $\begin{array}{l}17.38 \mathrm{c} \\
\pm 0.04\end{array}$ & $47.51 *$ & 0.00 & 2193.3 & 0.00 \\
\hline $\begin{array}{l}\text { Net calorific value }\left(\mathrm{MJ} \cdot \mathrm{kg}^{-1}\right) \\
\pm \mathrm{S}_{\mathrm{x}}\end{array}$ & $\begin{array}{l}17.36 \mathrm{a} \\
\pm 0.03\end{array}$ & $\begin{array}{l}16.92 \mathrm{~b} \\
\pm 0.56\end{array}$ & $\begin{array}{l}16.35 \mathrm{c} \\
\pm 0.24\end{array}$ & $\begin{array}{l}16.21 \mathrm{c} \\
\pm 0.04\end{array}$ & $53.96^{*}$ & 0.00 & 2529.05 & 0.00 \\
\hline Moisture (\%) & 7.51 & 7.41 & 8.70 & 12.29 & - & - & - & - \\
\hline $\operatorname{Ash}(\%) \pm \mathrm{S}_{\mathrm{x}}$ & $\begin{array}{l}21.98 \mathrm{a} \\
\pm 2.34\end{array}$ & $\begin{array}{l}12.75 \mathrm{~b} \\
\pm 0.31\end{array}$ & $\begin{array}{l}8.55 \mathrm{c} \\
\pm 0.25\end{array}$ & $\begin{array}{l}12.95 \mathrm{~b} \\
\pm 2.11\end{array}$ & $152.49 *$ & 0.00 & - & - \\
\hline Carbon $(C)(\%) \pm \mathrm{S}_{\mathrm{x}}$ & $\begin{array}{l}47.66 \mathrm{a} \\
\pm 0.18\end{array}$ & $\begin{array}{l}44.34 \mathrm{~b} \\
\pm 0.37\end{array}$ & $\begin{array}{l}44.45 \mathrm{~b} \\
\pm 0.22\end{array}$ & $\begin{array}{l}43.07 \mathrm{c} \\
\pm 0.13\end{array}$ & 193.24* & 0.00 & - & - \\
\hline Hydrogen $(\mathrm{H})(\%) \pm \mathrm{S}_{\mathrm{x}}$ & $\begin{array}{l}6.32 \mathrm{a} \\
\pm 0.04\end{array}$ & $\begin{array}{l}5.88 \mathrm{~b} \\
\pm 0.06\end{array}$ & $\begin{array}{l}6.06 \mathrm{c} \\
\pm 0.01\end{array}$ & $\begin{array}{l}6.64 \mathrm{~d} \\
\pm 0.05\end{array}$ & $191.61 *$ & 0.00 & - & - \\
\hline Nitrogen $(N)(\%) \pm S_{x}$ & $0.88 \pm 0.12$ & $0.63 \pm 0.02$ & $0.89 \pm 0.33$ & $0.55 \pm 0.07$ & 0.14 & 0.93 & 1.12 & 0.44 \\
\hline Sulfur $(\mathrm{S})(\%) \pm \mathrm{S}_{\mathrm{x}}$ & $\begin{array}{l}0.14 \mathrm{a} \\
\pm 0.00\end{array}$ & $\begin{array}{l}0.12 \mathrm{~b} \\
\pm 0.00\end{array}$ & $\begin{array}{l}0.12 \mathrm{~b} \\
\pm 0.00\end{array}$ & $\begin{array}{l}0.13 \mathrm{a} \\
\pm 0.00\end{array}$ & $7.67 *$ & 0.00 & - & - \\
\hline
\end{tabular}

$\mathrm{S}_{x}$ - standard deviation; *Significant value of the $\mathrm{F}$ test at significance level $\alpha=0.05 ; a, b, c, d$-Significant difference at the level of significance of $\alpha=0.05 ; F-\mathrm{F}$ test; $F_{w}-$ Welch's F test, $p_{w}-$ p-value for Welch's $\mathrm{F}$ test

Determining emission levels of individual gases and dust was based on the factor's emission method. The $\mathrm{CO}_{2}$ emission factor was calculated using the calculation method based on the carbon content and calorific value of fuels. Formulas 4-6 were used for the calculations [37]:

$$
\begin{array}{ll}
\mathrm{SO}_{2}: & E=B \cdot w \cdot S \\
\mathrm{NO}_{2} / \mathrm{CO} / \mathrm{CO}_{2}: & E=B \cdot w \\
& E=\frac{B \cdot w \cdot A \cdot 100}{(100-K)}
\end{array}
$$

...where $\mathrm{E}$ is amount of emission $(\mathrm{kg}), \mathrm{B}$ is fuel consumption $(\mathrm{Mg}), \mathrm{S}$ is sulfur content in fuel $(\%), \mathrm{A}$ is ash content in fuel $(\%), \mathrm{K}$ is combustible components content in dust ( $5 \%$ for biomass) $(\%)$, and $\mathrm{w}$ is emission ratio.

The results underwent statistical analysis conducted by means of STATISTICA 13 software. The normality of distribution of the properties under consideration was checked by means of the Shapiro-Wilk compliance test. The impact of a certain matter upon the value of incineration gross and net calorific value, ash content, $\mathrm{C}, \mathrm{H}, \mathrm{N}$, and $\mathrm{S}$ content was assessed by means of the ANOVA test. Homogeneity of variance was checked by Lavene's test. In the case of heterogeneity of variance, the $\mathrm{F}$ Welch test $\left(\mathrm{F}_{\mathrm{w}}\right)$ was performed. The significance level of diversity was also confirmed by means of the Tukey (HSD) test. All statistical analyses were conducted at the significance level of $\alpha=0.05$.

\section{Results and Discussion}

In the course of our research, we measured the incineration gross and net calorific values for oak, hazel, maple, and walnut leaves (Table 1). The measurements were repeated 10 times for each type of leaf. The results of the received state of the fuels confirms the lower calorific value, lower sulfur content, and lower ash compared to hard coal [37]. The research output figures for the incineration gross and net calorific value allowed us to demonstrate differences among the species of tree leaves that had undergone analysis. The highest values were proven by oak tree leaves. The average value of the incineration gross calorific value for that kind of matter stood at $18.58 \mathrm{MJ} \mathrm{kg}^{-1}$. The second ranked species of tree leaves proving the higher value of the incineration gross calorific value was the maple tree leaf. Its average value of incineration gross calorific value for that kind of matter stood at $18.00 \mathrm{MJ} \mathrm{kg}^{-1}$. The remaining leaves under consideration (maple and walnut) did not vary much in terms of the incineration gross and net calorific values, i.e., they were diversified by approximately $0.01 \%$. The output figures for the values of physical and chemical properties of the tree leaves under consideration underwent statistical analysis in order to assess the impact of the species of tree leaves on the level of the incineration gross and net calorific values. The Shapiro-Wilk test for all analyzed data in work confirm the normality of distribution of the properties under consideration with the significance level of $\alpha=0.05$. In next step the ANOVA test of two factors was performed. Four groups of leaf varieties were compared (Table 1).

The ANOVA test proved that the kind of matter under consideration did have an impact indeed upon 
Table 2. Comparison of estimated gas-dust emission ratios for biomass.

\begin{tabular}{|c|c|c|c|c|c|c|}
\hline Material & Unit & $\mathrm{CO}$ & $\mathrm{NO}_{\mathrm{x}}$ & $\mathrm{CO}_{2}$ & $\mathrm{SO}_{2}$ & Dust \\
\hline Oak tree leaves & $\mathrm{kg} \cdot \mathrm{Mg}^{-1}$ & $58.72 \mathrm{a}$ & $1.95 \mathrm{a}$ & $1438.00 \mathrm{a}$ & $2.44 \mathrm{a}$ & $27.76 \mathrm{a}$ \\
\hline Maple tree leaves & $\mathrm{kg} \cdot \mathrm{Mg}^{-1}$ & $54.63 \mathrm{~b}$ & $2.24 \mathrm{~b}$ & $1337.80 \mathrm{~b}$ & $2.13 \mathrm{~b}$ & $16.11 \mathrm{~b}$ \\
\hline Hazel tree leaves & $\mathrm{kg} \cdot \mathrm{Mg}^{-1}$ & $54.75 \mathrm{~b}$ & $1.99 \mathrm{a}$ & $1340.82 \mathrm{c}$ & $2.07 \mathrm{~b}$ & $10.80 \mathrm{c}$ \\
\hline Walnut tree leaves & $\mathrm{kg} \cdot \mathrm{Mg}^{-1}$ & $53.07 \mathrm{c}$ & $1.96 \mathrm{a}$ & $1299.52 \mathrm{~d}$ & $2.40 \mathrm{a}$ & $16.36 \mathrm{~b}$ \\
\hline Hard coal [37] & $\mathrm{kg} \cdot \mathrm{Mg}^{-1}$ & 82.01 & 4.09 & 1969 & 5.20 & 23.57 \\
\hline
\end{tabular}

$a, b, c, d$-Significant difference at the level of significance of $\alpha=0.05$

the level of gross calorific value incineration and net calorific value. The significance of the diversity of the groups was measured by means of the Tukey HSD test (Table 1). The Tukey HSD test proved that the properties under consideration are substantially diversified in those groups for the majority of the values of $p<0.05$. Only in the case of the walnut and hazel leaves did the output figures not vary significantly among these two groups.

The research output figures for the ash content for the four species of tree leaves under consideration (incinerated at $600^{\circ} \mathrm{C}$ ) have been presented in the Table 1. The research output figures make it plausible to state that the highest ash content was demonstrated by the oak tree leaves $-22 \%$ - and the lowest at $9 \%$ for hazel. The difference of the ash content between hazel and maple approximated $4 \%$. The second top ash content was proven by the walnut tree at $13 \%$. The research output figures for ash content in the four varieties of tree leaves underwent statistical analysis. ANOVA was also performed for the four varieties of leaves. The ANOVA test proved that the variety of leaves had a considerable impact upon ash content. Therefore, the significance of diversity among the groups was confirmed by the Tukey HSD test and it proved that only in the case of maple and walnut did the research output figures not vary significantly among these two groups (Table 1).

For incineration of the samples under consideration, the resulting figures for carbon, hydrogen, nitrogen, and sulfur contents in the leaves under consideration were determined. In the course of our research, the percentage rates of the content of chemical elements under consideration were computed (Table 1). The ANOVA test proved that the type of species of tree leaves significantly influenced the contents of carbon, hydrogen, and sulfur. No significant difference was reported for nitrogen content. Therefore, the significance level of the differences between carbon, hydrogen, and sulfur was confirmed. The Tukey HSD test proved that only in the case of oak and walnut did they vary significantly among all the groups as far as carbon content was concerned. In the case of hydrogen content, significant diversity was recorded for all groups. For sulfur content differences were shown between oak, walnut, maple, and hazel.

The calculated emission values are presented in Table 2. The figures show that $\mathrm{CO}_{2}$ and $\mathrm{SO}_{2}$ emissions are lower during the combustion of biomass fuel (tree leaves) compared to hard coal. In addition, lower emission ratios of coal emission gases may be observed. The highest emission factors were observed among $\mathrm{CO}$ (28.39\% lower than hard coal), $\mathrm{CO}_{2}$ (26.97\% lower than hard coal), $\mathrm{SO}_{2}$ (53.07\% lower than hard coal), and dust (15\% higher than hard coal) for oak. The highest NOx emissions were found for maple tree leaves (45.23\% lower than hard coal). The lowest emission rates $\mathrm{CO}$ (35.28\% lower than hard coal) and $\mathrm{CO}_{2}(34 \%$ lower than hard coal) were found for walnut, while $\mathrm{SO}_{2}$ (60.19\% lower than hard coal) and dust (54.17\% lower than hard coal) for hazel. Based on the obtained results it can be stated that the advantages of the analyzed biomass are lower values of emission factors compared to conventional fuels (coal). The ANOVA test proved that the variety of leaves had a considerable impact upon emission ratios for biomass. Therefore, the significance of diversity among the groups was confirmed by the Tukey HSD test and it proved that in all groups of emission factors output figures vary significantly among whole groups (Table 2). No significant differences were found between the leaves of the maple and the hazel in $\mathrm{CO}$ emission. Significant differences in $\mathrm{NO}_{\mathrm{x}}$ emissions were found only for maple in relation to other materials. Tukey HSD test in terms of $\mathrm{SO}_{2}$ emissions showed significant differences between oak and walnut, and maple and hazel. In the case of emissions of $\mathrm{CO}_{2}$ and dust, the Tukey HSD test showed significant differences between all groups.

In the case of the studied biomass sources, only for nitrogen oxides was there an increase in their level per unit of energy in relation to hard coal (Table 3).

For oak, the highest emission rates per unit of energy were observed for $\mathrm{CO}$ (12.1\% lower than hard coal), $\mathrm{CO}_{2}$ (13.25\% lower than hard coal), $\mathrm{SO}_{2}$ (50\% lower than hard coal also for walnut tree leaves), and dust (27.84\% higher than hard coal). The highest NOx emissions were reported for maple (69.23\% lower than hard coal). The lowest emission factors for CO $(21.14 \%$ lower than hard coal) and $\mathrm{CO}_{2}(4.02 \%$ higher than hard coal) were observed for maple, $\mathrm{SO}_{2}(57.14 \%$ lower than hard coal) for maple and hazel, dust (53.50\% lower than hard coal) for hazel, and NOx (69.63\% lower than hard coal) for the three others. The ANOVA test proved that the variety of leaves had a considerable impact on gas-dust emission 
Table 3. Gas-dust emission indices for biomass per unit of energy.

\begin{tabular}{|c|c|c|c|c|c|c|}
\hline Material & Unit & $\mathrm{CO}$ & $\mathrm{NO}_{\mathrm{x}}$ & $\mathrm{CO}_{2}$ & $\mathrm{SO}_{2}$ & Dust \\
\hline Oak tree leaves & $\mathrm{kg} \cdot \mathrm{GJ}^{-1}$ & $3.34 \mathrm{a}$ & 0.11 & $81.70 \mathrm{a}$ & 0.14 & $1.58 \mathrm{a}$ \\
\hline Maple tree leaves & $\mathrm{kg} \cdot \mathrm{GJ}^{-1}$ & $3.10 \mathrm{~b}$ & 0.13 & $76.01 \mathrm{~b}$ & 0.12 & $0.92 \mathrm{~b}$ \\
\hline Hazel tree leaves & $\mathrm{kg} \cdot \mathrm{GJ}^{-1}$ & $3.11 \mathrm{~b}$ & 0.11 & $76.18 \mathrm{~b}$ & 0.12 & $0.61 \mathrm{c}$ \\
\hline Walnut tree leaves & $\mathrm{kg} \cdot \mathrm{GJ}^{-1}$ & $3.02 \mathrm{~b}$ & 0.11 & $73.84 \mathrm{c}$ & 0.14 & $0.93 \mathrm{~b}$ \\
\hline Hard coal $[37]$ & $\mathrm{kg} \cdot \mathrm{GJ}^{-1}$ & 3.83 & 0.04 & 70.87 & 0.28 & 1.14 \\
\hline
\end{tabular}

$a, b, c, d$-Significant difference at the level of significance of $\alpha=0.05$

indices for biomass per unit of energy in all groups except $\mathrm{NO}_{x}$ and $\mathrm{SO}_{2}$. Therefore, the significance of diversity among the groups was confirmed by the Tukey HSD test and it proved that in the groups of emission factors, per unit of energy varies significantly among whole groups for $\mathrm{CO}, \mathrm{CO}_{2}$, and dust emission (Table 3). The analysis of $\mathrm{CO}$ emissions showed significant differences between the oak leaves and other materials. The Tukey HSD test also showed that $\mathrm{CO}_{2}$ emissions are not significantly different for the maple leaves and hazel leaves in the studied group. In the case of walnut and maple, the output figures for dust emissions did not vary significantly among these two groups.

On the grounds of the related literature, Table 4 presents the elementary composition of certain kinds of energy sources in terms of carbon, hydrogen, nitrogen, and sulfur content, and it was compared with the leaves under consideration and energy crops, i.e., Jerusalem artichoke sunflower and Reynoutria sachalinensis, oneyear-old sprouts of Salix viminalis, oak timber, potato starch residue, and hard coal.

The highest content of carbon (C) is represented by hard coal, followed by oak timber, oak leaves, and energy crops. The content of that chemical element in maple, hazel, and walnut is a bit lower, but it approximates the content of other energy sources. The highest percentage share of hydrogen $(\mathrm{H})$ is represented by the potato starch residue, followed by walnut and oak. The percentage share of nitrogen $(\mathrm{N})$ in the matter under

Table 4. Elemental composition of selected types of energy raw materials [21, 38-40].

\begin{tabular}{|c|c|c|c|c|}
\hline Material & $\begin{array}{c}\mathrm{C} \\
(\%)\end{array}$ & $\begin{array}{c}\mathrm{H} \\
(\%)\end{array}$ & $\begin{array}{c}\mathrm{N} \\
(\%)\end{array}$ & $\begin{array}{c}\mathrm{S} \\
(\%)\end{array}$ \\
\hline Jerusalem artichoke sunflower & 45.77 & 6.08 & 0.31 & 0 \\
\hline Reynoutria sachalinensis & 46.81 & 5.69 & 0.38 & 0 \\
\hline $\begin{array}{c}\text { Salix viminalis } \\
\text { (one-year-old sprouts) }\end{array}$ & 44.96 & 5.79 & 0.70 & 0 \\
\hline Oak timber & 49.00 & 6.00 & 0.20 & 0.21 \\
\hline Potato starch residue & 43.35 & 7.31 & 1.21 & 0.44 \\
\hline Miscanthus & 48.4 & 6.0 & 0.4 & 0 \\
\hline Hard coal & 75.7 & 4.3 & 1.2 & 1.2 \\
\hline
\end{tabular}

consideration is the highest in the case of the potato starch reside and hard coal. The most efficient property, that is the lowest content of those chemical elements, is represented by energy crops and oak timber. The matter under consideration proved to contain nitrogen $(\mathrm{N})$ similar to in one-year-old sprouts of Salix viminalis. In comparison to the remaining energy crops, the content of elementary chemical elements is generally similar. According to Fournel et al. [21], Miscanthus has a high nitrogen content and it is higher than the maximum obtained in studies for the oak leaves of $1.04 \%$. While comparing the obtained results for sulfur content (S) it can be stated that the analyzed biomass has a lower content compared to other plants and hard coal.

Table 5 presents physicochemical properties of selected types of leaves obtained in research by Garcia et al. [18] and Fernandes et al. [41] in order to compare with results obtained in research. Analysis of the obtained results with literature data suggests that the results for gross calorific value of all leaves is comparable with that of the leaves of other species of trees.

According to Fernandes et al. [41], the gross calorific value for the oak leaves in their research was lower by $1.07 \mathrm{Mg} \cdot \mathrm{kg}^{-1}$ than that obtained in studies. It could also be noticed that analyzed leaves of the hazel had gross calorific value of only $0.46 \mathrm{Mg} \cdot \mathrm{kg}^{-1}$ higher. By comparing the gross calorific value of all the other leaves from the literature, it can be concluded that the highest value was found in banana leaves at $19.8 \mathrm{Mg}^{*} \mathrm{~kg}^{-1}$, which is $1.22 \mathrm{Mg} \cdot \mathrm{kg}^{-1}$ higher than the one obtained for the oak leaves, which was the highest value in the studies. Both analyzed leaves of hazel and walnut are characterized by a gross calorific value at a similar level as the leaves of apple, cherry, orange, and peach. However, in the case of oak and maple their gross calorific value is similar to the gross calorific value of banana $\left(19.8 \mathrm{Mg}^{\cdot} \mathrm{kg}^{-1}\right)$ and peach

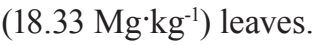

While comparing the ash content of the studied leaves of trees it can be noticed that the highest value has been obtained from oak leaves (21.98\%), whose value is very high. The literature data for this kind of raw material is only $3.8 \%$. The difference can be the result of species of oak. Analyzing the obtained ash from the leaves of maple (12.75\%) and walnut (12.95\%), it can be stated that they are comparable to the ash content from leaves of orange (15.4\%) and peach (10.2\%). 
Table 5. Physicochemical properties of selected types of tree leaves [18, 41].

\begin{tabular}{|c|c|c|c|c|c|c|c|}
\hline Material & $\begin{array}{l}\text { Gross calorific value } \\
\left(\mathrm{MJ} \cdot \mathrm{kg}^{-1}\right)\end{array}$ & Moisture (\%) & $\begin{array}{l}\text { Ash } \\
(\%)\end{array}$ & $\mathrm{C}(\%)$ & $\mathrm{H}(\%)$ & $\mathrm{N}(\%)$ & S (\%) \\
\hline Apple tree & 17.51 & 9.3 & 12.0 & 44.45 & 6.15 & 1.61 & 0.23 \\
\hline Cherry tree & 17.73 & 10.4 & 7.4 & 45.52 & 6.25 & 1.49 & 0.19 \\
\hline Huzelnut tree & 17.87 & 9.10 & 8.0 & 45.52 & 6.25 & 1.49 & 0.31 \\
\hline Oak tree & 17.51 & 9.1 & 3.8 & 46.90 & 5.47 & 3.04 & 0.38 \\
\hline Orange tree & 16.17 & 9.2 & 15.4 & 41.11 & 5.28 & 2.59 & 0.40 \\
\hline Peach tree & 18.33 & 7.44 & 10.02 & 59.59 & 9.79 & 2.03 & 0.77 \\
\hline Almond tree & 17.56 & 7.5 & 9.3 & 43.25 & 5.50 & 2.85 & 0.23 \\
\hline Banana tree & 19.8 & 8.3 & 8.7 & 43.5 & 6.3 & 1.3 & 0.2 \\
\hline
\end{tabular}

The ash content of hazel leaves is comparable with the literature data for leaves of cherry, almond, apple, or banana, and does not differ more than $1.85 \%$ for the results obtained.

Elemental analyses were comparable to the content of both carbon $(\mathrm{C})$ and hydrogen $(\mathrm{H})$ for the analyzed raw materials and with literature data for other species of tree leaves. It can be seen that the highest carbon (C) content for the analyzed samples was seen in oak leaves. In comparison to data with other samples and the literature data, the ash content is higher by approximately $2 \%$. Only as indicated by Fernandes et al. [41] did carbon content for peach leaf differ from the data obtained in studies and literature. For this kind of leaf the ash content is slightly higher by about approximately $12 \%$. The hydrogen content is similar for all tested materials and the literature data for other species of tree leaves. Only for the peach leaves was the hydrogen content about 3.5\% lower than the obtained results.

The obtained content of nitrogen $(\mathrm{N})$ for the tested material is at a similar level and is in the range $0.55-0.89 \%$. By comparing the obtained values with the literature data it can be concluded that oak, maple, walnut, and hazel leaves have the lowest content of this element relative to the literature data. It can also be stated that the greatest differences are in relation to almond leaves. In this case the nitrogen content is $2.3 \%$ lower relative to the walnut leaves by $2.2 \%$ compared to maple, and approximately $2 \%$ relative to the leaves of hazel and oak. The smallest differences are in relation to the banana leaves. We should mention the difference for leaves of walnut $0.94 \%$ to $0.86 \%$ maple leaves, and the leaves of oak and hazel $0.6 \%$. It should also be noted that the results obtained for sulfur content are lower for all analyzed cases than for other tree species in literature. The difference in sulfur content is 0.05 $0.65 \%$, depending on the plant.

The presented emission rates indicate a reduction of 28-35\% CO, 24-53\% $\mathrm{NO}_{\mathrm{x}}, 26-32 \% \mathrm{CO}_{2}, 53-60 \%$ $\mathrm{SO}_{2}$, and $31-54 \%$ dust depending on the type of used biomass. Only in the case of oak tree leaves did a dust emission ratio increase by $17 \%$ in relation to hard coal. It should be noted that the use of leaves of trees (biomass) as fuel significantly reduces the emission of harmful compounds to the natural environment. Hence, the possibility of developing this type of fuel gives real environmental benefits, which is very important for the environment.

\section{Conclusions}

The use of biowaste for producing energy contributes to a reduction of emissions of hazardous substances and consequently to protection of the natural environment as well as to a reduction in the use of conventional fuel. The use of alternative fuel causes the emission of hazardous substances to be reduced and the international pro-ecological obligation, required by global renewable energy sources organizations, to be satisfied. In consequence, it is necessary to seek innovative environmentally friendly energy sources such as plant biomass that may also be derived from green waste. Biomass is particularly environmentally friendly because the volume of carbon dioxide emitted into the atmosphere in the course of its incineration is balanced by the volume of $\mathrm{CO}_{2}$ that is absorbed by plants that produce biomass in the course of the photosynthesis process. Using leaves that have fallen out for power generation purposes will allow us to arrange urban areas and to reduce the volume of solid waste to be landfilled. Research has proven that the physical and chemical properties of the leaves under consideration indicate a considerable energy potential of that type of solid waste. Therefore, it is plausible to state that in comparison with other energy sources, tree leaves may contribute to the diversification of energy as far as the energy and fuel balance in the national economy is concerned. The related literature that has been studied and the research that has been conducted provide for the following conclusions:

1) Of the matter under consideration, oak leaves have proven to show the best energy properties with 
an incineration gross calorific value at $18.58 \mathrm{MJ} \cdot \mathrm{kg}^{-1}$ and net calorific value at $17.36 \mathrm{MJ} \cdot \mathrm{kg}^{-1}$, whereas the walnut tree leaves have proven to show the smallest energy efficiency with an incineration gross calorific value at $17.38 \mathrm{MJ} \mathrm{kg}^{-1}$ and net calorific value at

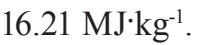

2) Research has proven that the biomass under consideration distinguished itself by the considerable content of ash ranging from $21.98 \%$ for oak tree leaves to $8.55 \%$ for hazel tree leaves. Notwithstanding, the leaves may be used as a source of thermal power to the extent of the biomass incineration technology and co-incineration technology as well as other plant-derived biomass thermal and chemical conversion technologies.

3) The statistical analysis of the research output figures at the significance level of $\alpha=0.05$ has proven the considerable impact of a kind of plant biomass upon the incineration gross and net calorific value, as well as the ash and hydrogen content $(\mathrm{H})$ and carbon content $(\mathrm{C})$.

4) Estimated emission factors for the studied biomass show lower emissions of up to $32 \% \mathrm{CO}_{2}, 53 \% \mathrm{NO}_{x}$, and $60 \% \mathrm{SO}_{2}$ relative to hard coal. This provides the basis for a positive assessment of this kind of biomass as green fuel.

\section{References}

1. VIANA H., COHEN W.B., LOPES D., ARANHA J. Assessment of forest biomass for use as energy. GIS-based analysis of geographical availability and locations of woodfired power plants in Portugal. App. Energy, 87 (8), 2551, 2010.

2. SZMIGIELSKI M., PIEKARSKI W., ANDREJKO D., SLASKA-GRZYWNA B., MASLOWSKI A., ZAJĄC G., SAGAN A., JAŚKIEWICZ T., RACHANCZYK I. Recovery of fatty substances from post-frying waste materials by extraction with hexane. Przem. Chem., 93 (5), 649, 2014.

3. CHANDEL A.K., DA SILVA S.S., CARVALHO W., SINGH O. V. Sugarcane bagasse and leaves: foreseeable biomass of biofuel and bio-products. J. Chem. Technol. Biot., 87 (1), 11, 2012.

4. PAJAZK T. Incineration of municipal waste - needs, realities and prospects of construction (in Polish). Thermal waste treatment. Restructuring thermal processes, Wandrasz, J.W.; Publisher Futura: Poznań, Poland, 2007.

5. KIMMING M., SUNDBERG C., NORDBERG Å., BAKY A., BERNESSON S., HANSSON P. A. Replacing fossil energy for organic milk production-potential biomass sources and greenhouse gas emission reductions. J. Clean. Prod., 106, 400, 2015.

6. ROBERTS J.J., CASSULA A.M., PRADO P.O., DIAS, R.A., BALESTIERI J.A.P. Assessment of dry residual biomass potential for use as alternative energy source in the party of General Pueyrredón, Argentina. Renew. Sust. Energ. Rev., 41, 568, 2015

7. KUMAR A., KUMAR N., BAREDAR P., SHUKLA A. A review on biomass energy resources, potential, conversion and policy in India. Renew. Sust. Energ. Rev., 45, 530, 2015.
8. NAKOMCIC-SMARAGDAKIS B., CEPIC Z., DRAGUTINOVIC N. Analysis of solid biomass energy potential in Autonomous Province of Vojvodina. Renew. Sust. Energ. Rev., 57, 186, 2016.

9. GARCIA-MARAVER A., PEREZ-JIMENEZ J.A. SERRANO-BERNARDO F., ZAMORANO M., Determination and comparison of combustion kinetics parameters of agricultural biomass from olive trees. Renew. Energ., 83, 897, 2015.

10. SEVIK H., CETIN M., GUNEY K., BELKAYALI N. The influence of house plants on indoor $\mathrm{CO}_{2}$. Pol. J. Environ. Stud., 26 (4), 1643, 2017.

11. CETIN M., SEVIK H. Measuring the impact of selected plants on indoor $\mathrm{CO}_{2}$ concentrations. Pol. J. Environ. Stud. 25(3), 973, 2016.

12. CETIN M., SEVIK H., ISINKARALAR K. Changes in the particulate matter and $\mathrm{CO}_{2}$ concentrations based on the time and weather conditions: the case of Kastamonu. Oxid. Commun. 40 (1-II), 477, 2017.

13. CETIN M. A Change in the Amount of $\mathrm{CO}_{2}$ at the Center of the Examination Halls: Case Study of Turkey. Stud.on Ethno-Med. 10 (2), 146, 2016.

14. SEVIK H., CETIN M., BELKAYALI N. Effects of Forests on Amounts of $\mathrm{CO}_{2}$ : Case Study of Kastamonu and Ilgaz Mountain National Parks. Pol. J. Environ. Stud., 24 (1), 253, 2016.

15. SHI Y., GE Y., CHANG J., SHAO H, TANG Y. Garden waste biomass for renewable and sustainable energy production in China: potential, challenges and development. Renew. Sust. Energ. Rev., 22, 432, 2013.

16. MACFARLANE D.W. Potential availability of urban wood biomass in Michigan: Implications for energy production, carbon sequestration and sustainable forest management in the U.S.A. Biomass Bioenerg., 33 (4), 628, 2009.

17. DZIEWANOWSKA M., DOBEK T. Energy-related and ecological evaluation of heat acquisition process during combustion of leaves picked in urban areas (in Polish), Inz. Rol., 1 (110), 115, 2009.

18. GARCÍA R., PIZARRO C., LAVÍN A.G., BUENO J.L. Characterization of Spanish biomass wastes for energy use. Bioresource technol., 103 (1), 249, 2012.

19. JAHIRUL M. I., RASUL M. G., CHOWDHURY A. A., ASHWATH N. Biofuels production through biomass pyrolysis - a technological review. Energies, 5 (12), 4952, 2012.

20. TUMULURU J.S., LIM C.J., BI X.T., KUANG X., MELIN S., YAZDANPANAH F., SOKHANSANJ S. Analysis on storage off-gas emissions from woody, herbaceous, and torrefied biomass. Energies, 8 (3), 1745, 2015.

21. FOURNEL S., PALACIOS J.H., MORISSETTE R., VILLENEUVE J., GODBOUT S., HEITZ M., SAVOIE P. Influence of biomass properties on technical and environmental performance of a multi-fuel boiler during on-farm combustion of energy crops. Appl. Energ., 141, 247, 2015.

22. SKIBA K., TYS A. Alternative sources of energy in the Lubelskie province (a rewiev). Acta Agroph., 14 (2), 449, 2009.

23. STOLARSKI M., SZCZUKOWSKI S., TWORKOWSKI J. Biofuels from perennial energy crops (in Polish). Energetyka, 1 (643), 77, 2008.

24. STRZELCZYK F., WAWSZCZAK A. The effectivity of the biomass as energy-fuel. Ryn. Ener., 5, 51, 2008.

25. SZYSZLAK-BARGLOWICZ J., ZAJAC G., PIEKARSKI W. Energy biomass characteristics of chosen plants. Int. Agroph., 26 (2), 175, 2012. 
26. SPYRIDAKI N.A., FLAMOS A. A paper trail of evaluation approaches to energy and climate policy interactions. Renew. Sust. Energ. Rev., 40, 1090, 2014.

27. KLIOPOVA I., MAKARSKIENE் K. Improving material and energy recovery from the sewage sludge and biomass residues. Waste Manage., 36, 269, 2015.

28. PASSARINI F., NICOLETTI M., CIACCI L., VASSURA I., MORSELLI L. Environmental impact assessment of a WtE plant after structural upgrade measures. Waste manage., 34 (4), 753, 2014.

29. BROECKX L.S., VERLINDEN M.S., CEULEMANS R. Establishment and two-year growth of a bio-energy plantation with fast-growing Populus trees in Flanders (Belgium): Effects of genotype and former land use, Biomass Bioenerg., 42, 151, 2012.

30. ZAJACC G., SZYSZLAK-BARGŁOWICZ J., WASILEWSKI J., KURANC A. Emission characteristics of biomass combustion in a domestic heating boiler fed with wood and Virginia mallow pellets. Fresen. Environ. Bull., 26 (7), 4663, 2017.

31. EN 14780: 2011 Solid biofuels - Sample preparation.

32. EN 14918:2010 Solid biofuels - Determination of calorific value.

33. EN 14775: 2010 Solid biofuels - Determination of ash content.

34. EN 14774-1: 2010 Solid biofuels - Determination of moisture content - Oven dry method - Part 1: Total moisture - Reference method.
35. EN ISO 16948:2015-07 Solid biofuels. Determination of total content of carbon, hydrogen and nitrogen.

36. EN ISO 16994:2016 Solid biofuels. Determination of total content of sulphur and chlorine

37. BORYCKA B. Commodity Study on Food and Energy Utilization of Rich-Food Waste of the Fruit and Vegetables Industry. Monograph. Publisher Radom University of Technology, Radom, Poland, 2008 [In Polish].

38. KOMOROWICZ M., WRÓBLEWSKA H., PAWŁOWSKI J. Chemical composition and energetic properties of biomass from selected renewable resources. Environ. Prot. Nat. Res., 40, 402, 2009.

39. SZYMANOWICZ R. Production of energy from renewable sources in the process of combustion of mixed secondary fuel containing biomass. Energetyka, 5, 298, 2011.

40. LALAK J., MARTYNIAK D., KASPRZYCKA A., ŻUREK G., MOROŃ W., CHMIELEWSKA M., WIĄCEK D., TYS J. Comparison of selected parameters of biomass and coal. Int. Agroph., 30 (4), 475, 2016.

41. FERNANDES E.R.K., MARANGONI C., SOUZA O., SELLIN N. Thermochemical characterization of banana leaves as a potential energy source. Energ. Convers. Manage., 75, 603, 2013. 